\title{
APLINKOS APSAUGOS SUBSIDIJŲ REIKŠMĖ APLINKAI IR EKONOMIKAI: TEORINIS POŽIŪRIS
}

\author{
Kristina Gesevičiené ${ }^{1}$, Baiba Rivza² ${ }^{2}$ Astrida Miceikiené $\dot{3}^{3}$ \\ ${ }^{1}$ Dokt. Vytauto Didžiojo Universitetas. Universiteto 10, Akademija, Kauno raj., Lietuva. \\ El. paštas kristina.geseviciene@vdu.lt \\ ${ }^{2}$ Prof. dr. Latvijos gyvybès mokslu ir technologijų universitetas. Liela g. 2, Jelgava, Latvija. El. paštas b.rivza@llu.lv \\ ${ }^{3}$ Prof. dr. Vytauto Didžiojo Universitetas. Universiteto 10, Akademija, Kauno raj., Lietuva. \\ El.paštas astrida.miceikiene@vdu.lt
}

Pateikta 202006 22; Priimta 20200831

\begin{abstract}
Klimato pokyčiai jau daro platų poveiki ekosistemoms, ekonomikos sektoriams ir žmonių sveikatai bei gerovei. Viena pagrindinių klimato kaitos problemų yra ịvardijama šiltnamio efektą sukeliančių dujų kiekio atmosferoje tolimesnis augimas. Subsidijos daro reikšmingą įtaką ekonomikai, tuo pačiu neigiamai veikiant aplinką, todèl jų taikymas turètų būti tobulinamas. Tyrimo tikslas yra identifikavus tiesioginių aplinkos apsaugos subsidijų ir mokesčių lengvatų apibrežtț ir paskirtị, teoriškai pagrịsti jų reikšmę aplinkai ir ekonomikai. Moksliniuose tyrimuose daugiausia dèmesio skiriama tiesioginių aplinkosaugos subsidiju vertinimui, o mokesčių subsidijoms, kaip ,paslèptoms“ nebiudžetinèms subsidijoms skirta mažiau dèmesio. Europos Sajunga yra ịsipareigojusi pašalinti aplinkai žalingas subsidijas, siekiant neutralizuoti poveikị klimatui ir ịgyvendinti socialiai teisingą ir ekonomiškai efektyvią verslo remimo pertvarką. Tyrime išanalizuota subsidijos apibrež̌tis, identifikuotos aplinkos apsaugos subsidijų rūšys, teoriškai pagrịsta jų reikšmė aplinkai ir ekonomikai.
\end{abstract}

Raktiniai žodžiai: aplinkos apsauga, subsidijos apibrež̌tis, aplinkai žalingos subsidijos.

JEL kodai:Q50, Q56, Q58.

\section{Ivadas}

Pasaulyje didejjant aplinkos taršai bei sparčiai augant gamtos išteklių naudojimui, vis daugiau dèmesio skiriama aplinkos apsaugai. Vyksta įvairios diskusijos, atliekami moksliniai tyrimai aplinkos apsaugos srityje, nes tiek ekonominis, tiek aplinkosaugos, tiek socialinis šalių vystymasis priklauso nuo aplinkos ir kraštovaizdžio būklès bei biologinès įvairovès išsaugojimo, taip pat nuo racionalaus gamtinių išteklių naudojimo. Taršos, gamtos išteklių naudojimo bei klimato kaitos problemos yra vienos svarbiausių daugelyje išsivysčiusių ir besivystančių šalių, nes nuo jų sprendimo priklauso ne tik gyventojų sveikata, bet ir visos šalies ekonomikos augimas.

Viena pagrindinių įvardijamų beatodairiškos aplinkos išnaudojimo pasekmių yra klimato atšilimas. Kova su klimato atšilimu ir žala aplinkai - visuotinai pripažinta problema. Klimato kaita kelia grèsmę pagrindiniams pasaulio žmonių gyvenimo elementams: prieigai prie vandens, maisto gamybai, sveikatai ir žemès bei aplinkos naudojimui (Stern, N., 2006). Siekiant sumažinti klimato atšilimą, buvo pasirašytas Kioto protokolas, kuris ịpareigojo valstybes sumažinti i atmosferą išmetamų teršalų kiekį. $2015 \mathrm{~m}$. Paryžiaus susitarimu išsivysčiusios šalys buvo ịpareigotos imtis sparčių ir efektyvių priemonių pereinant prie mažo anglies dioksido technologijų naudojimo, o besivystančios šalys pagal savo galimybes ịsipareigojo aktyviai prisidèti prie atmosferos taršos mažinimo. Tačiau net ir praejjus dvejiems metams po Paryžiaus susitarimo, anglies dioksido išmetimas auga, iškastinis kuras - dominuojanti energijos rūšis, o auganti paklausa ir toliau veikia natūralius išteklius, didèja ūminè ekosistemos degradacija, vandens streso intensyvumas, toliau auga oro ir vandens užterštumo įtaka sveikatai (Ekonominio ..., 2017).

Copyright (C) 2020. Published by Vytautas Magnus University. This is an open access article distributed under the terms of the Creative Commons Attribution Non-Commercial 4.0 (CC BY-NC 4.0) license, which permits unrestricted use, distribution, and reproduction in any medium provided the original author and source are credited. The material cannot be used for commercial purposes. 
Valstybès, siekdamos sumažinti neigiamas klimato kaitos pasekmes, taiko įvairias aplinkosaugos priemones. Tai aplinkos taršos leidimai, aplinkos apsaugos subsidijos, aplinkos mokesčiai ir kt. Šių priemonių taikymui reikia nemažų finansinių išteklių. Tačiau ir jas pasitelkus, klimato kaitos problemos, ypač susijusios su aplinkos apsauga, išlieka kone aktualiausia tema tam tikrose šalyse, Europos Sąungos (toliau ES) institucijose, pasaulinėse organizacijose, ji itin svarbi politikams, mokslininkams ir vyriausybėms.

Politikai ir vyriausybės ieško aplinkos taršos mažinimo variantų, racionaliausių finansinių išteklių paskirstymo sprendimų. Mokslininkai analizuoja aplinkos taršos priežastis, pasekmes, jie prognozuoja, taip pat ieško efektyvesnių kovos su aplinkos tarša priemonių, nagrinèja taikomų taršos mažinimo priemonių efektyvumą.

Išanalizavus mokslinę literatūrą (Pereira, H., Withana, S., ten Brink, P., Franckx, L., Hirschnitz-Garbers, M., Mayeres,I., Oosterhuis, F., Porsch, L., Stern N., Ekins, P., Speck, S., Čiegis R., Patterson III, C.D., Nichols, A. L., Mayrand, K., Dionne, S., Paquin, M., Pageot-LeBel, I., Moltke, A. V., McKee, C. ir Morgan, ir kt.), kurioje nagrinejjamos aplinkos apsaugos priemonès - jų reikšmè, efektyvumas, veiksmingumas, taikymo galimybės, paaiškejjo, kad mokslininkai išsamiai nagrinejja atskiras aplinkos taršos mažinimui skirtas priemones, ypač subsidijas ir mokesčius, tačiau pasigendama nuodugnios ir kompleksinès analizès šiomis svarbiomis temomis: minètų priemonių integruoto ekonominio ir aplinkosauginio poveikio aplinkos taršos mažinimui vertinimo bei mokesčių lengvatų, kaip aplinkos apsaugos vienos iš subsidijų, integravimo ị ši vertinimą. Šiai problemai pagrịsti būtinas sisteminis požiūris ị aplinkos apsaugos subsidijų reikšmę kovojant su klimato kaitos pasekmèmis.

Šio tyrimo tikslas - identifikavus tiesioginių aplinkos apsaugos subsidijų ir mokesčių lengvatų apibrěžtį ir paskirtį, teoriškai pagrịsti jų reikšmę aplinkai ir ekonomikai. Tyrimo objektas aplinkos apsaugos subsidijos.

Tyrimo metodika. Siekiant pagrịsti problemos aktualumą, bus pasitelkti tokie teoriniai metodai: mokslinès literatūros analizè, lyginamoji analizè, sisteminè analizè, dokumentų analizè, apibendrinamoji analizè ir kiti bendramoksliniai metodai. Aplinkos apsaugos subsidijų apibrēžčiai formuoti naudotas operacionalizacijos metodas. Analizuojant aplinkos apsaugos subsidijų paskirtị teoriniu požiūriu taikytas bibliometrinis metodas. Analizuoti Lietuvos ir užsienio mokslininkų atlikti tyrimai, publikuoti moksliniuose leidiniuose, referuojamuose ir indeksuojamuose tarptautinėse duomenų bazėse: Web of Science, Scopus, EBSCO, Springer.

\section{Tyrimo rezultatai}

Aplinkos apsaugos subsidijos yra vienas iš ekonominio aplinkos apsaugos mechanizmo veiksnių. Mokslinèje literatūroje daugiau nagrinejjamos aplinkos apsaugos tiesioginès subsidijos ir jų poveikis taršos mažinimui, o mokesčių lengvatų poveikio vertinimo tyrimų aptikta nedaug. Tyrimų, kaip šios priemonès veikia kartu, nerasta. Lietuvoje tokių tyrimų nėra atlikta. Todėl svarbu nustatyti, kiek veiksmingai aplinkos apsaugos subsidijos ir mokesčių lengvatos veikia išmetamų i aplinką teršalų mažinimą ir tvarią plètrą.

Prieš vertinant, ar aplinkos apsaugos subsidijos daro poveiki aplinkos taršai arba padeda gerinti aplinkos apsaugą, būtina apibrèžti, kas turi būti laikoma subsidijomis, kokias funkcijas jos atlieka. Subsidijų apibrèžties nustatymą, kuris apimtų skirtingų šalių nacionalinius prioritetus bei kuo ịvairesnes subsidijų rūšis, tiek Visuotinių subsidijų iniciatyva (toliau GSI, angl. The Global Subsidies Initiative), tiek Pasaulio Prekybos Organizacija (toliau PPO) įvardina kaip pirmiausią žingsni prieš pradedant subsidijų duomenų analizès ir poveikio vertinimo procesą. Subsidija plačiąja prasme (lot. subsidium - pagalba, palaikymas) - pašalpa, dotacija, ekonominès pagalbos teikimas privačiam sektoriui, gamintojams arba kurios nors prekès vartotojams. plati subsidijos apibrèžtis turètų apimti bet kokio pobūdžio lengvatinị režimą - finansinį ir kitokị - vartotojams ir gamintojams (Lang et al, 2010). 
Subsidijų apibrèžtis yra problema, kurią gvildena tiek tarptautinès organizacijos (GSI, EBPO, PPO), tiek mokslininkai (Sovacool, 2017; Skovgaard, 2017; Kojima ir Kolpow, 2015; Valsecchi et al., 2009; Mayrand, Dionne, Paquin ir Pageot-LeBel 2003; Withana et al., 2012). Subsidiju ivvairovė sukelia sunkumų aiškinantis jų tikslus ir pobūdị. Kartais subsidijas nèra lengva identifikuoti ir palyginti. Subsidijų apibrèžtis kito per pastaruosius dvidešimti metų: nuo Ekonominio bendradarbiavimo ir plètros organizacijos (toliau EBPO) apibūdinimo kaip taikomų priemonių ịtakos vartotojų ar gamintojų mokamai kainai ar patiriamoms išlaidoms, iki kitokių apibrezžčių, susijusių su vis ịvairesnèmis subsidijų rūšimis bei jų teikimo įrankiais (1 lentelè). PPO apibrèžia subsidiją kaip vyriausybės arba vyriausybès atstovo finansini įnašą, suteikiantị naudos jo gavèjams. Taip pat skirtingiems veiklos sektoriams tarptautinès organizacijos bei jų ekspertai yra išplètoję atskirus subsidijų apibrèžimus - Tarptautinè Energetikos agentūra (toliau TEA) apibrèžia, kas laikoma energijos subsidija, EBPO pateikia atskiras žemès ūkio subsidijų, žvejybos subsidijų apibrèžtis, Kojima ir Koplow (2015) apibrèžia, kas laikoma iškastinio kuro subsidija.

\section{1 lentelè. Subsidijos apibrèžtis}

\begin{tabular}{|c|c|c|c|}
\hline Šaltinis & Metai & Apibrèžtis & Taikymas \\
\hline EBPO & 1997 & $\begin{array}{l}\text { Subsidija - tai bet kokia priemonė, kurią taikant kainos } \\
\text { vartotojams yra žemesnès nei rinkos kainos, o gamintojams - } \\
\text { aukštesnès nei rinkos, arba tai sumažina išlaidas vartotojams ir } \\
\text { gamintojams teikiant tiesioginę ar netiesioginę kainų paramą. }\end{array}$ & $\begin{array}{l}\text { De Moor ir Calamai } \\
\text { (1997); van Beers et al. } \\
\text { (2001); Moltke et al., } \\
\text { (2004) }\end{array}$ \\
\hline EBPO & 2002 & $\begin{array}{l}\text { Subsidija - vyriausybès vykdomos politikos teikiama nauda } \\
\text { asmenims ar įmonems, kuri padidina jų pajamas arba sumažina } \\
\text { sąnaudas ir daro itaką gamybai, vartojimui, prekybai, pajamoms } \\
\text { ir aplinkai. Politikos teikiama nauda gali būti ivairi, pvz., } \\
\text { produkcijos kainos padidèjimas, sąnaudų sumažèjimas, mokesčių } \\
\text { nuolaidos, palūkanų normos nuolaidų suteikimas ar tiesioginiai } \\
\text { biudžeto pervedimai. }\end{array}$ & $\begin{array}{l}\text { Mayrand et al. (2003); } \\
\text { Portugal (2002) }\end{array}$ \\
\hline EBPO & 2005 & $\begin{array}{l}\text { Subsidija - vyriausybės veiksmų rezultatas, suteikiantis } \\
\text { vartotojams ar gamintojams pranašumo, siekiant padidinti jų } \\
\text { pajamas arba sumažinti išlaidas. Mokesčiu lengvatos yra kitokia } \\
\text { subsidijų forma. }\end{array}$ & Valsecchi et al. (2009) \\
\hline PPO & $\begin{array}{l}2006, \\
1999\end{array}$ & 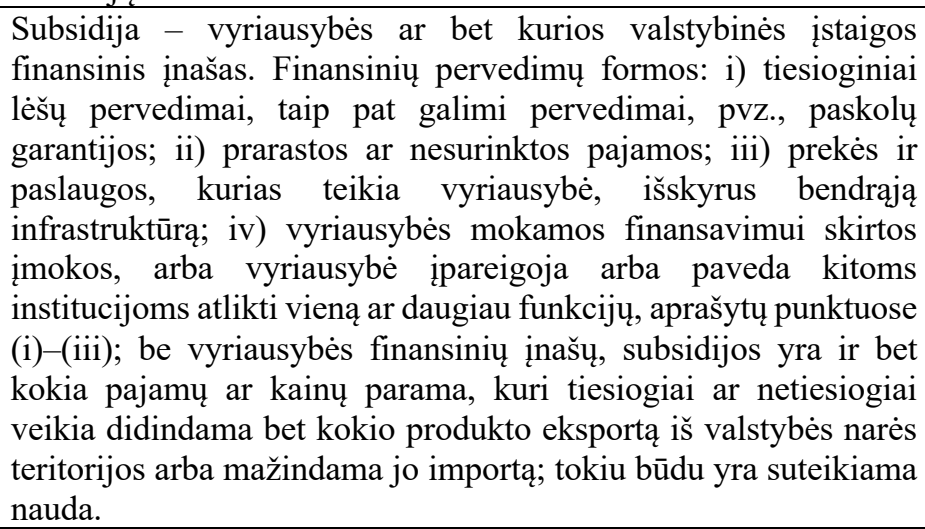 & $\begin{array}{l}\text { Lang et al (2010); } \\
\text { Sovacool } \\
\text { Steenblik (2017); }\end{array}$ \\
\hline $\begin{array}{l}\text { Nacionalinių } \\
\text { sąskaitu } \\
\text { sistema }\end{array}$ & $\begin{array}{l}2008 \\
1993\end{array}$ & $\begin{array}{l}\text { Subsidijos yra einamieji neatlyginami mokèjimai, kuriuos } \\
\text { vyriausybiniai vienetai, iskaitant vyriausybinius vienetus - } \\
\text { nerezidentus, moka įmonėms atsižvelgiant i jų gamybos apimtis } \\
\text { ar kiekius, arba jų gaminamu, parduodamų ar importuojamų } \\
\text { prekių ar paslaugų kiekị ar vertę. }\end{array}$ & PPO (2006) \\
\hline
\end{tabular}

Mokslininkai linkę pasitelkti EBPO subsidijų apibrèžtị, kuria EBPO taip pat remiasi kaip pagrindu klasifikuoti subsidijas ir kuria jų vertinimo metodus (Valsecchi et al., 2009: Mayrand et al., 2003; Moltke et al., 2004). Tuo tarpu GSI Didžiojo dvidešimtuko (G20) grupės narèms rekomenduoja PPO (2006) taikomą subsidijų apibrèžti, kuri apima plačią subsidijų taikymo sriti, grindžiama subsidijos perkèlimo metodu, ir aiškiai atskiria subsidijos apibrèžimą ir vertinimą, ar jos naudojimas yra pateisinamas. PPO vienijant daugiau nei pusantro šimto narių, tai yra viena iš plačiausiai taikomų 
subsidijų apibrèžčių, naudota derybų procesuose, paremta išsamia teisine analize. Tai suteikia pranašumų lyginant su kita kuria subsidijų apibrèžtimi.

Tarptautinių organizacijų keliama problema - i subsidijų apibrèžti neįtraukiamas išorinis subsidijos poveikis - tai papildomos išlaidos aplinkai ir visuomenei. Kitson et al. (2011) teigia, kad nepilnas tokių išlaidų įtraukimas yra subsidija. Šalims skirtingai apibrèžiant subsidijas, jų vertinimui ir dydžio apskaičiavimui gali būti pasirenkamos ne tos pačios vyriausybių taikomos intervencinès priemonės. Naudojama subsidijų apibrėžtis ịtakoja subsidijų dydžio vertinimą (Skovgaard, 2017; Kojima ir Koplow, 2015).

Mokslinèje literatūroje egzistuoja du požiūriai i subsidijų apibrèžtį. Vienas iš jų remiasi „poveikio testu“ - subsidija egzistuoja, jei ji turi tam tikrą poveikį, pavyzdžiui, keičiasi kainos. Tokių apibrěžimų apribojimas yra tas, kad dažnai poveiki gali sukelti daugiau nei viena vyriausybès intervencija. Kitas požiūris vertina subsidijų perdavimo formas, identifikuojant politikos priemonių, naudojamų perduodant subsidijos išmoką gavejjui, rūšis. PPO (2006) nuomone, subsidijų apibrěžtys paprastai siekia apibrěžti ị vieną iš šių vyriausybès intervencijos ypatybių, siekiant apriboti subsidijų sąvoką: subsidijų gavejjus, subsidijų formą, jų tikslus ir poveikį.

Subsidijų skirstymas i ịvairias rūšis pagal jų teikimo instrumentą tiesiogiai siejasi su subsidijos apibrèžtimi. 2 lentelèje pateiktos mokslininkų ir tarptautinių organizacijų išskiriamos subsidijų rūšys pagal teikimo instrumentą.

2 lentelè. Subsidijų rūšių ir jų apibrèžčių sąsajos (sudaryta autorių remiantis Valsecchi et al., 2009; Moltke et al., 2004; Čiegis, 2009)

\begin{tabular}{|c|c|c|c|c|c|c|}
\hline \multirow[t]{2}{*}{ Subsidijos rūšis } & \multicolumn{6}{|c|}{ Subsidijos apibrèžties naudojimas (autoriai) } \\
\hline & ESA & PPO & EBPO & Pieters & $\mathrm{UN}$ & Čiegis \\
\hline \multicolumn{7}{|c|}{$\begin{array}{ll}\text { Biudžetinès subsidijos } \\
\end{array}$} \\
\hline (a) Tiesioginis lèšų pervedimas, pvz., dotacijos & $\mathrm{X}$ & $\mathrm{X}$ & $\mathrm{X}$ & $\mathrm{X}$ & $\mathrm{X}$ & $\mathrm{X}$ \\
\hline $\begin{array}{l}\text { (b) Galimi tiesioginiai lèšu pervedimai, pvz., } \\
\text { insipareigojimų padengimas }\end{array}$ & & $\mathrm{X}$ & $\mathrm{X}$ & $\mathrm{X}$ & & $\mathrm{X}$ \\
\hline $\begin{array}{l}\text { (c) Vyriausybė teikiamos prekès ar paslaugos (išskyrus } \\
\text { bendrają infrastruktūrą) }\end{array}$ & & $\mathrm{X}$ & $\mathrm{X}$ & $\mathrm{X}$ & & \\
\hline $\begin{array}{l}\text { (d) Vyriausybės nurodymai kitoms institucijoms atlikti } \\
\text { aukščiau išvardytus veiksmus }\end{array}$ & & $\mathrm{X}$ & $\mathrm{X}$ & $\mathrm{X}$ & & \\
\hline \multicolumn{7}{|c|}{ Nebiudžetinès subsidijos } \\
\hline (e) Pajamų ar kainų palaikymas & & $\mathrm{X}$ & $\mathrm{X}$ & $\mathrm{X}$ & $\mathrm{X}$ & $\mathrm{X}$ \\
\hline (f) Prarandamos arba nesurenkamos valdžios pajamos & & $\mathrm{X}$ & $\mathrm{X}$ & $\mathrm{X}$ & & \\
\hline (g) Mokesčių lengvatos ir nuolaidos & & $\mathrm{X}$ & $\mathrm{X}$ & $\mathrm{X}$ & $\mathrm{X}$ & $\mathrm{X}$ \\
\hline (h) Lengvatinè prieiga prie rinkos & & $\mathrm{X}$ & $\mathrm{X}$ & $\mathrm{X}$ & & \\
\hline (i) Pagreitintos nusidèvejjimo sąnaudos & & & $\mathrm{X}$ & $\mathrm{X}$ & & \\
\hline $\begin{array}{l}\text { (j)Reguliaciniai paramos mechanizmai, pvz., tarifų, } \\
\text { paklausos kvotų }\end{array}$ & & & $\mathrm{X}$ & $\mathrm{X}$ & $\mathrm{X}$ & \\
\hline (k) Tam tikros išimtys nuo taikomų valdžios standartų & & & $\mathrm{X}$ & $\mathrm{X}$ & $\mathrm{X}$ & \\
\hline (1) Išteklių nuoma esant prarastiems gamtos ištekliams & & & $\mathrm{X}$ & $\mathrm{X}$ & & \\
\hline $\begin{array}{l}\text { (m) Netiesioginès subsidijos, pvz., infrastruktūros } \\
\text { teikimas }\end{array}$ & & & & $\mathrm{X}$ & & \\
\hline $\begin{array}{l}\text { (n) Netiesioginiai pajamų pervedimai, atsirandantys } \\
\text { esant nustatytai nevisai kainai }\end{array}$ & & & & $\mathrm{X}$ & & \\
\hline $\begin{array}{l}\text { (o) Netiesioginiai pajamų pervedimai, atsiradę dèl } \\
\text { neinternalizuotų išorès veiksnių }\end{array}$ & & & & $\mathrm{X}$ & & \\
\hline
\end{tabular}

Lentelès informacija leidžia padaryti išvadą, kad tiesioginès subsidijos ir mokesčiai daugelio mokslininkų ir tarptautinių organizacijų išskiriami kaip pagrindiniai, taip pagrindžiamas jų tyrimo kontekstas. Šiame tyrime tiesioginès aplinkos apsaugai skiriamos subsidijos ir su aplinkos apsauga susijusios mokesčių lengvatos ịvardijamos kaip aplinkos apsaugos subsidijos, pagrindžiančios jų integruotą ekonominị ir aplinkosauginị vertinimą. 
Europos aplinkos politikos instituto mokslininkai subsidijas klasifikuoja i dvi grupes: biudžetines ir nebiudžetines. Biudžetinėmis subsdijomis laikomos valstybès nacionalinio biudžeto išlaidos, apimančios tiesioginius piniginius mokẻjimus gamintojams, vartotojams ir kitiems susijusiems asmenims. Nebiudžetinès subsidijos apima kainų palaikymą, mokesčių lengvatas, nuolaidas, netiesioginius pajamų pervedimus ir kitas lengvatinio apmokestinimo formas. Tiek tiesioginès subsidijos, tiek mokesčių lengvatos gali būti priskirtos aplinkos taršos išlaidoms mažinti (Moltke et al., 2004; Čiegis, 2009), jų požymiai: išlaidų mažinimas, prekès kainos mažinimas, įmonès veiklos rodiklių gerinimas, pajamų didinimas.

Pasaulio banko duomenimis, $2017 \mathrm{~m}$. subsidijoms skiriamos šalių lèšos sudarè 26.6 proc. visų biudžeto išlaidų (Lietuvos - 31,1 proc. biudžeto išlaidų). Tarptautinių organizacijų ekspertai energijos subsidijas įvardija kaip vienas didžiausių, kurioms atitenka reikšminga valstybių biudžeto dalis (EBPO, 2003). EBPO ir TAE duomenimis, $2017 \mathrm{~m}$. kietojo kuro subsidijos vertinant 76 šaliu ekonomikas, augo 5 proc. lyginant su 2016 m., ir sieke 340 milijardų JAV dolerių. 2018 metų duomenys atskleidžia, kad kietojo kuro subsidijos toliau augo ir sudarè daugiau nei 400 milijardų JAV dolerių. Tokios subsidijos skatina iškastinio kuro gamybą ir naudojimą, vartotojų subsidijos aukštesnị vartojimo lygị, kas didina ŠESD emisijas, teršia vandenį, gadina kraštovaizdị. Atitinkamai vertinama, kad tokių kietojo kuro subsidijų atsisakymas padètų sumažinti ŠESD emisijas 18 procentų iki 2050 metų (Lockwood, 2015). Atsižvelgiant ị energijos sektoriaus subsidijoms skiriamą reikšmingą mokslinių tyrimų dalị, siekiant apibrèžti subsidijų sampratą, ịvertinant jų atliekamas funkcijas, išanalizuota mokslinèje literatūroje dažniausiai tiriamų energijos subsidijų tema. Mokslininkai daro išvadą, kad įvairios valstybès intervencijos formos teikiant energijos subsidijas, pvz., tiesiogines finansines išmokas, lengvatinị apmokestinimą, prekybos apribojimus, energetikos sektoriaus reguliavimą ar su energetika susijusias paslaugas, kurias tiesiogiai teikia vyriausybè mažesniais kaštais, skirtingai veikia gamybos kaštus arba prekès kainą vartotojui (1 pav). Šiu subsidijų analize iš dalies gali būti grindžiama aplinkos apsaugos subsidijų paskirtis. 


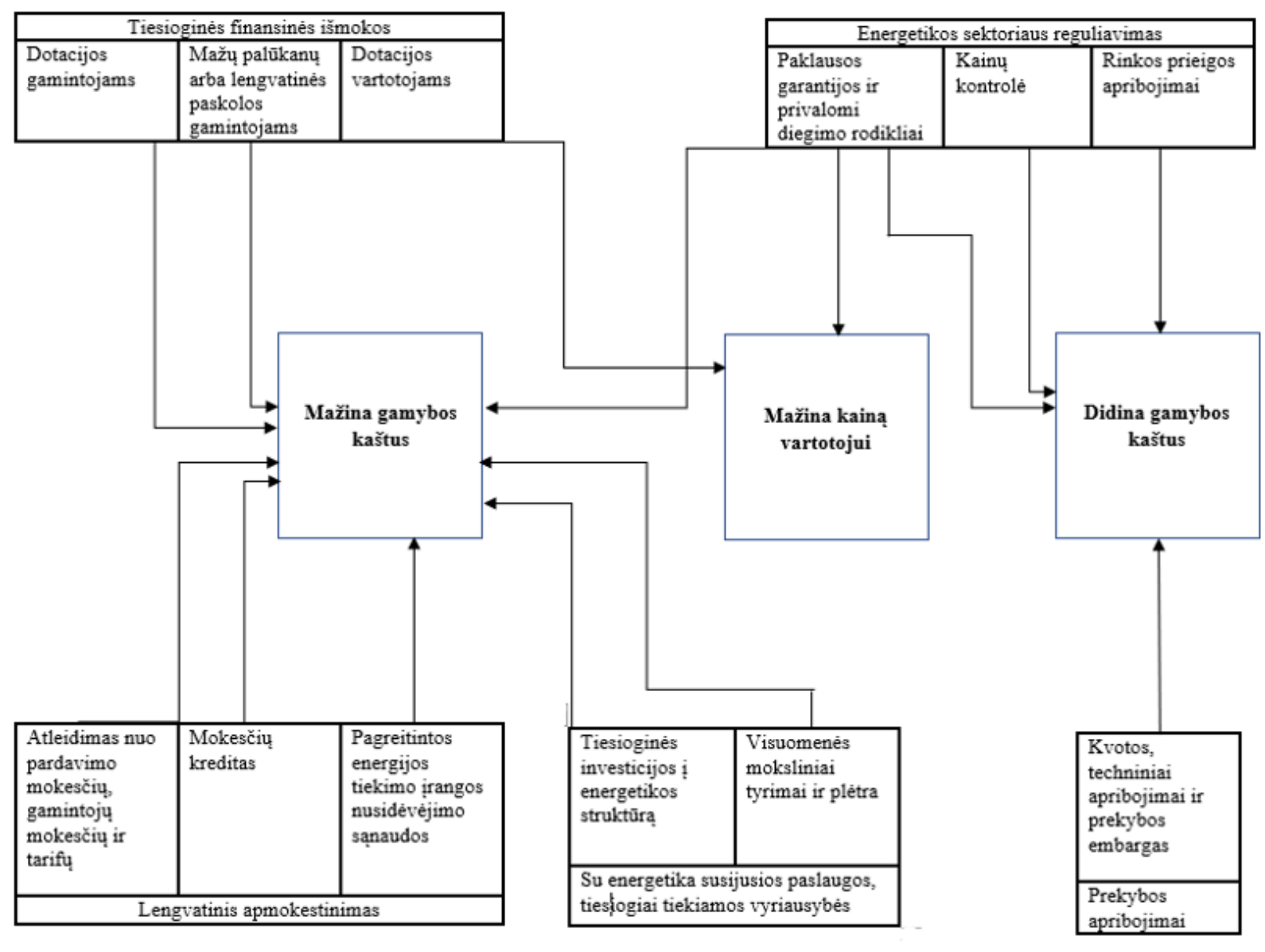

1 pav. Energijos subsidijų tipai ir jų veikimo įtaka (sudaryta autorių remiantis Pereira, 2018; Moltke et al., 2004)

Tiesioginès finansinès išmokos, lengvatinis apmokestinimas, Vyriausybès tiesiogiai teikiamos paslaugos mažina gamybos kaštus, kai sektoriaus reguliavimo priemonès bei prekybos apribojimai didina gamybos kaštus.

Dar vienas aplinkos apsaugos subsidijų požymis yra jų nauda/žala aplinkai. Subsidija apibrèžiama kaip ,aplinkai žalinga“, jei ji skatina didesnę žalą aplinkai, nei tokia veikla būtų daroma be subsidijos (EBPO, 2003). Plačiau ši kategorija apibrèžiama kaip vyriausybès veiksmų rezultatas, suteikiantis vartotojams ar gamintojams pranašumo, siekiant padidinti jų pajamas arba sumažinti jų išlaidas, tačiau tuo pat metu darant žalą aplinkai (Withana et al., 2012).

Subsidijos, veikdamos kaštų mažinimą, palengvina įmonių patekimą i verslo sektorių bei jų konkurencingumą ir paskatina atitinkamo sektoriaus prekių gamybą bei kartu su tuo susijusius neigiamus poveikius, t. y. taršos mąstą bei ŠESD emisijas (Čiegis, 2009). Subsidijų žemès ūkiui augimas lèmé suintensyvèjusią žemès ūkio gamybą, kuri, savo ruožtu, vertinama kaip kenksminga aplinkai dèl pesticidų ir trąšų naudojimo, buveinių naikinimo ir žemès degradacijos, lemianti didejjančią specializaciją ir mažejjančią biologinę ịvairovę (Mayrand et al., 2003; Lingard, 2001; EBPO, 2005). Kietojo kuro, naftos, energijos subsidijos prisideda prie ŠESD emisijų augimo (EBPO, 2005; Moltke et al., 2004). Šiltnamio efektą sukeliančios dujos sukelia žalingo ir galimai negrịžtamo poveikio riziką ekosistemoms, visuomenei ir ekonomikai (Stern, 2006).

EBPO jau kurị laiką akcentuoja būtinybę reformuoti arba atsisakyti aplinkai žalingų subsidijų, jas ịvardydama kaip vieną veiksnių, nepadedančių igyvendinti darnios vystymosi politikos tikslus. Europos Sajunga yra seniai įsipareigojusi pašalinti arba palaipsniui panaikinti aplinkai žalingas subsidijas. Tokie įsipareigojimai buvo priimti tiek pasauliniu, tiek nacionaliniu, vietos ir regionų 
lygiu, šalims dalyvaujant Europos aplinkos politikos instituto atliekamose studijose dèl aplinkai žalingų subsidijų nustatymo. Neigiamai vertinami aplinkos apsaugos subsidijų taikymo aspektai, potencialiai galintys daryti žalą aplinkai, apibendrintai pateikiami 3 lentelèje.

\section{3 lentelè. Neigiamai vertinami aplinkos apsaugos subsidijų taikymo aspektai (parengta autorių remiantis Withana et al., 2012; Stern, 2006)}

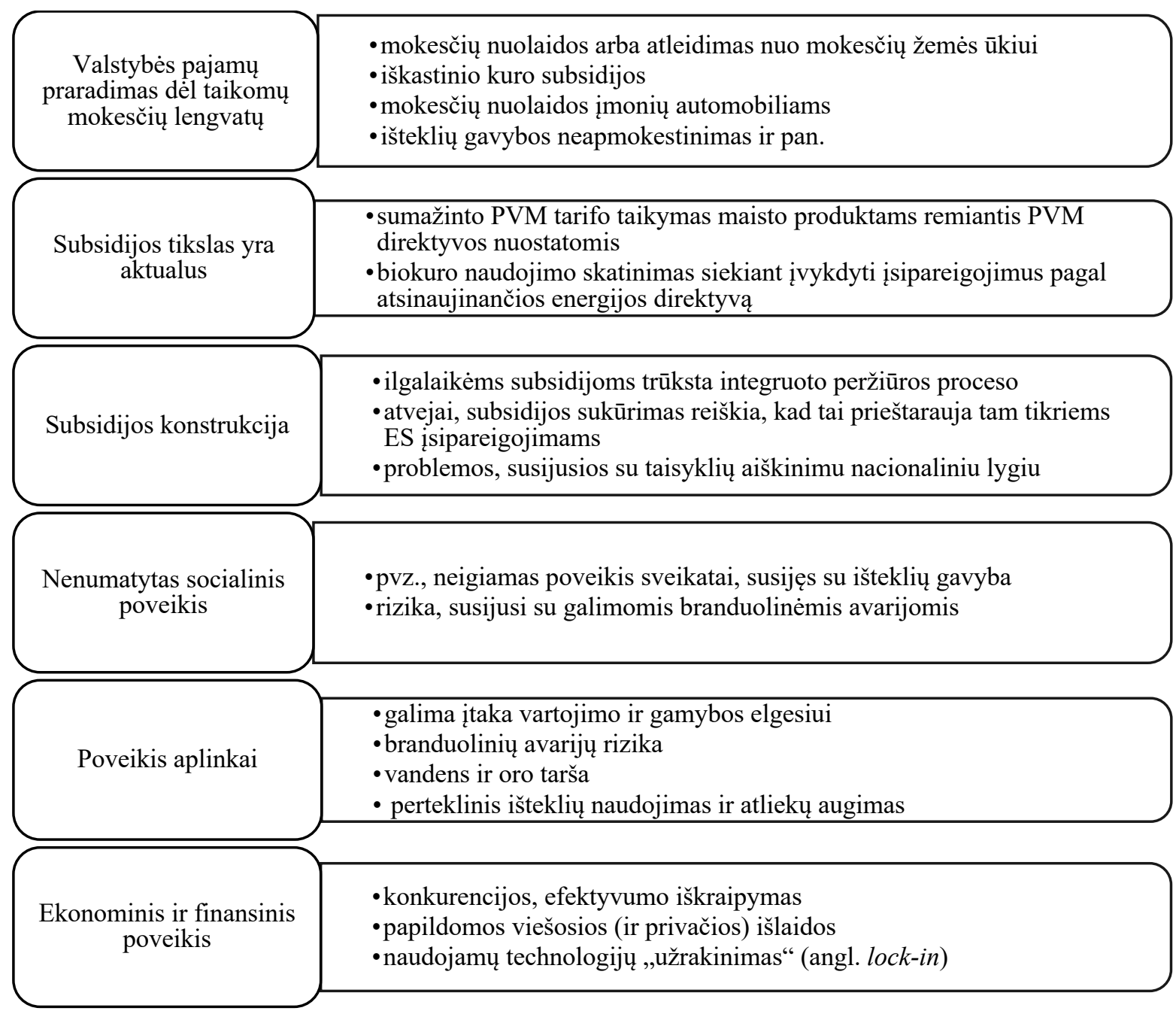

Pagrindžiant tyrimo aktualumą pabrèžiama, kad aplinkos apsaugos subsidijos turi būti peržiūrimos ir vertinamos, ar tikslas, kuriam skirtos subsidijos, vis dar aktualus, ar subsidijos nukreiptos teisinga linkme ir veikia integruotai, ar neprieštarauja ES teisės aktams, ar neturi neigiamo socialinio, aplinkosauginio, ekonominio ar finansinio poveikio (Withana et al., 2012). Šalys, ketindamos taikyti aplinkos apsaugos subsidijas ar igyvendinti esamų aplinkos apsaugos programų reformas, turètų laikytis keleto pagrindinių principų, aplinkos apsaugos subsidijų programos arba jų reformos turètų atitikti šiuos kriterijus (Moltke et al., 2004; Withana et al., 2012):

- tinkamai nukreipta: subsidijos turetų būti skiriamos tik tiems, kam yra skiriamos ir kas jų nusipelno;

- efektyvi: subsidijos neturètų trukdyti tiekejjų ar vartotojų paskatoms veiksmingai teikti ar naudotis paslauga;

- pagrịsta: subsidijos turètų būti pagrịstos išsamia susijusių išlaidų ir naudos analize;

- praktinè: subsidijos dydis turètų būti adekvatus, o jos administravimo kaštai turi būti maži;

- skaidri: visuomené turètų matyti, kiek kainuoja subsidijų programos ir kas gauna naudą;

- apribota laike: subsidijų programos turètų būti ribotos trukmès. 
Tyrimui pasirinkus nagrinèti aplinkos apsaugos subsidijas, būtina nurodyti jų skirstymo kriterijus - tokių subsidijų naudą arba žalą aplinkai. Subsidijos gali būti pateisinamos, jei padideja bendra socialinè gerovè (Moltke et al., 2004). Ši situacija susiklosto tada, kai socialinè nauda ar aplinkos gerinimas viršija ekonomines sąnaudas. Tačiau kai grynasis subsidijų poveikis yra neigiamas, bendra socialinè gerovè būtų didesnè be subsidijų. Aplinkai žalingų subsidijų identifikavimas ir jų sumažinimas yra vienas iš būdų siekti darnaus vystymosi (Moltke et al., 2004). Svarbu reformuoti aplinkai nepalankias subsidijas, ypač žemès ūkio ir energetikos srityse. Būtina teisingai ịvertinti ir nustatyti subsidijų poveikį, nes net įrodžius, kad tam tikra subsidija kenkia aplinkai, subsidijuojant galima remti kitus socialinius tikslus (EBPO, 2003).

Siekiant nustatyti aplinkos apsaugos subsidijų apibrèžtį, turinị ir rūšis, išanalizuota mokslinė literatūra. Subsidijos apibrěžtys, naudojamos mokslininkų ar tarptautinių organizacijų, paprastai yra pasirenkamos pagal subsidijų paskirtį ir gali skirtis, priklausomai nuo srities, kurioje taikomos. Subsidija - vyriausybės veiksmų rezultatas, suteikiantis vartotojams ar gamintojams pranašumo, siekiant padidinti jų pajamas arba sumažinti jų išlaidas; mokesčių lengvatos yra kitokia subsidijų forma. İvairūs mokslininkai subsidijų rūšis pagal atliekamas funkcijas vertina nevienareikšmiai. Kai tokios subsidijos taikymas kelia žalą aplinkai, ji įvardijama kaip aplinkai žalinga subsidija. Subsidijų taikymui būdinga nemažai neigiamai vertinamų aspektų, todèl, siekiant taikyti aplinkos apsaugos subsidijas ar reformuoti esamas, būtina laikytis subsidijoms keliamų principų. Subsidijos ekonomiškai prisideda prie verslo stiprinimo, tačiau yra žalingos aplinkai.

Apibendrinant išnagrinètą mokslinę literatūrą, teigtina, kad subsidijų ekonominis poveikis apima poveikị veiklos augimui, veiklos vietai, investicijoms, tarptautinei prekybai. Iprastai manoma, kad žemès ūkio, iškastinio kuro, žvejybos subsidijos dirbtinai didina produkcijos gamybą, mažina pasaulines kainas, iškreipia tarptautines rinkas ir tarptautinę prekybą, mažina ekonominị efektyvumą (Pereira, 2018; Čiegis, 2009; Stern, 2006; Mayrand, 2003; Lingard, 2001; ir kiti). Subsidijų poveikis aplinkai išryškejja per subsidijos poveiki produkcijos gamybos apimčiai ir suděčiai ekonomikoje bei gamybos ir vartojimo lygio sukeltas pasėkmes aplinkai. Subsidijos poveikis aplinkai priklauso nuo subsidijos poveikio taško ir nuo subsidijos dydžio, kuris lemia iškraipantị subsidijos poveiki paramos gavejjų sektoriuose. Jis yra glaudžiai susijęs su subsidijos ekonominiu poveikiu. Siekiant suprasti subsidijų poveikị ir ar jų reformavimas turès teigiamą rezultatą, būtina ekonominį, aplinkosauginị ir socialinị subsidijų poveikị vertinti integruotai.

\section{Išvados}

Subsidijos apibrèžtys, naudojamos mokslininkų ar tarptautinių organizacijų, paprastai yra pasirenkamos pagal subsidijų paskirti ir gali skirtis, priklausomai nuo srities, kurioje taikomos Mokslininkai tyrimuose analizuoja tiesiogines subsidijas, tačiau nevertina mokesčių lengvatų. Teoriniu požiūriu, subsidijas apima tiesioginè finansinè parama ir mokesčių lengvatos. Todèl siekiant visapusiškai ịvertinti aplinkos apsaugos subsidijų įtaką klimato kaitos valdymui būtina sistemiškai analizuoti ir vertinti abi subsidijų rūšis: tiesiogines subsidijas ir mokesčių lengvatas. Naudojama subsidijų apibrèžtis įtakoja subsidijų dydžio vertinimą

Nustatyta, kad ị subsidijų apibrezžti tyrimuose neittraukiamas išorinis subsidijos poveikis papildomos išlaidos aplinkai ir visuomenei. Šalims skirtingai apibrěžiant subsidijas, jų vertinimui ir dydžio apskaičiavimui gali būti pasirenkamos ne tos pačios vyriausybių taikomos intervencinès priemonès.

Išskirtos aplinkos apsaugos subsidijų teigiamos ir neigiamos savybės, kurios turi ịtaką klimato kaitos valdymo sprendimams priimti. Šių subsidijų daroma nauda ar žala aplinkai ir ekonomikai turi būti pagrindas formuojant aplinkos apsaugos politiką. Vertinant aplinkos apsaugos subsidijų įtaką klimato kaitos valdymo sprendimams turi būti taikomas holistinis požiūris ị jų daromą įtaką ekonomikai ir aplinkos apsaugai.

Išskirta aplinkos apsaugos subsidijų reikšmė aplinkai ir ekonomikai: 
- Subsidijų ekonominis poveikis apima poveiki veiklos augimui, veiklos vietai, investicijoms, tarptautinei prekybai. Mokslininkai pagrindžia, kad žemès ūkio, iškastinio kuro, žvejybos subsidijos dirbtinai didina produkcijos gamybą, mažina pasaulines kainas, iškreipia tarptautines rinkas ir tarptautinę prekybą, mažina ekonominị efektyvumą.

- Subsidijų poveikis aplinkai išryškèja per subsidijos poveiki produkcijos gamybos apimčiai ir sudéčiai ekonomikoje bei gamybos ir vartojimo lygio sukeltas pasekmes aplinkai. Subsidijos poveikis aplinkai priklauso nuo subsidijos poveikio taško ir nuo subsidijos dydžio, kuris lemia iškraipantį subsidijos poveikị paramos gavejjų sektoriuose.

Mokslininkai tyrimais pagrindžia, kad šiuo metu šalyse taikomos aplinkos apsaugos subsidijos dažnai daro žalą aplinkai, turi būti peržiūrimos ir vertinamos, ar tikslas, kuriam skirtos subsidijos, vis dar aktualus, ar subsidijos nukreiptos teisinga linkme ir veikia integruotai, ar neprieštarauja ES teisès aktams, ar neturi neigiamo socialinio, aplinkosauginio, ekonominio ar finansinio poveikio.

\section{Literatūros sąrašas}

Čiegis, R. (2009). Gamtos išteklių ir aplinkos ekonomika. Klaipėda: KU leidykla. 722 p.

De Moor, A., \& Calamai, P. (1997). Subsidizing unsustainable development: undermining the earth with public funds. Toronto: Earth Council.

Ekins, P., Speck, S. (2011) Competitiveness and Environmental Tax Reform. http://www.greenfiscalcommission.org.uk/images/uploads/gfcBriefing7_PDF_isbn_v8.pdf [2020 08 27]

European Commission, International Monetary Fund, Organisation for Economic Cooperation and Development, United Nations, and World Bank. (2009) // System of national accounts 2008. Prieiga per internetą: https://unstats.un.org/unsd/nationalaccount/docs/sna2008.pdf [2020 08 27]

Inter-Secretariat Working Group on National Accounts, \& Commission of the European Communities. (1993). System of national accounts 1993 (Vol. 2). International Monetary Fund. Prieiga per internetą: https://unstats.un.org/unsd/nationalaccount/docs/1993sna.pdf [2020 08 27]

Kitson, L., Wooders, P., \& Moerenhout, T. (2011). Subsidies and External Costs in Electric Power Generation: A comparative review of estimates. International Institute for Sustainable Development.

Kojima, M., \& Koplow, D. (2015). Fossil fuel subsidies: Approaches and valuation. Policy Research Working Paper 7220. Washington, DC: World Bank.

Kyoto Protocol to The United Nations Framework Convention on Climate Change. (1997). UN Doc. Prieiga per internetą: https:/unfccc.int/resource/docs/convkp/kpeng.pdf [2020 08 27]

Lang, K., Wooders, P., \& Charles, C. (2010). Defining Fossil-Fuel Subsidies for the G-20: Which Approach is Best?. Available at SSRN 1577690. Geneva: IISD-GSI.

Lingard, J. (2001). The Role of Agricultural Subsidies in Environmental Change. // Encyclopedia of Global Environmental Change. Vol. 3, Chichester: John Wiley: 168-171.

Lockwood, M. (2015). Fossil Fuel Subsidy Reform, Rent Management and Political Fragmentation in Developing Countries // New Political Economy, 20:4, 475-494. https://doi.org/10.1080/13563467.2014.923826

Mayrand, K., Dionne, S., Paquin, M., \& Pageot-LeBel, I. (2003). The economic and environmental impacts of agricultural subsidies: an assessment of the 2002 US farm bill and Doha round. Montreal, Canada: Unisféra International Centre, 76.

Moltke, A. V., McKee, C., \& Morgan, T. (2004). Energy subsidies: Lessons learned in assessing their impact and designing policy reforms. UNEP/ Earthprint, 2003, $170 \mathrm{p}$. 
Nichols, A. L. (1984). Targeting economic incentives for environmental protection. Cambridge, Mass.: MIT Press. 189 p.

OECD (2003), Environmentally Harmful Subsidies: Policy Issues and Challenges, OECD Publishing, Paris, https://doi.org/10.1787/9789264104495-en. [2020 08 27]

OECD. (2005). 2005 Annual report on sustainable development work in The OECD. Prieiga per internetą: https://www.oecd.org/greengrowth/36654376.pdf [2020 08 27]

OECD. (2017). OECD work on environment 2017-18. Prieiga per internetą: http://www.oecd.org/environment/OECD-work-on-environment-2017-2018.pdf [2020 08 27]

Patterson III, C. D. (2000). Environmental taxes and subsidies: what is the appropriate fiscal policy for dealing with modern environmental problems. Wm. \& Mary Envtl. L. \& Pol'y Rev., 24, $121 \mathrm{p}$.

Pereira, H. (2018). How the WTO can help tackle climate change through fossil fuel subsidy reform. ICTSD.

Portugal, L. (2002, November). OECD work on defining and measuring subsidies in agriculture. In OECD Workshop on Environmentally Harmful Subsidies, Paris (pp. 7-8).

Skovgaard, J. (2017). The devil lies in the definition: competing approaches to fossil fuel subsidies at the IMF and the OECD. // International Environmental Agreements: Politics, Law \& Economics, 17(3), 341-353.

Sovacool, B. K. (2017). Reviewing, reforming, and rethinking global energy subsidies: towards a political economy research agenda // Ecological Economics, 135, 150-163.

Stern, N. H., Peters, S., Bakhshi, V., Bowen, A., Cameron, C., Catovsky, S., ... \& Garbett, S. L. (2006). Stern Review: The economics of climate change (Vol. 30, p. 2006). Cambridge: Cambridge University Press.

Valsecchi, C., Ten Brink, P., Bassi, S., Withana, S., Lewis, M., Best, A., ... \& Soares, C. D. (2009). Environmentally harmful subsidies (EHS): Identification and assessment. Final report for the European Commission's DG Environment, November 2009.

van Beers, C., \& van den Bergh, J. C. (2001). Perseverance of perverse subsidies and their impact on trade and environment // Ecological Economics, 36(3), 475-486. https://doi.org/10.1016/S0921-8009(00)00245-7

Withana, S., ten Brink, P., Franckx, L., Hirschnitz-Garbers, M., Mayeres, I., Oosterhuis, F., and Porsch, L. (2012). Study supporting the phasing out of environmentally harmful subsidies. A report by the Institute for European Environmental Policy (IEEP), Institute for Environmental Studies - Vrije Universiteit (IVM), Ecologic Institute and Vision on Technology (VITO) for the European Commission - DG Environment. Final Report. Brussels. 2012. Prieiga per internetą: https://ec.europa.eu/environment/enveco/taxation/pdf/report phasing_out_env_harmful_subsidies.p df [2020 0827$]$

WTO. (2006). World Trade Report 2006. Exploring the links between subsidies, trade and the WTO. World Trade Organization (September 30, 2006). ISBN-10: 9287033528. Prieiga per internetą: https://www.wto.org/english/res_e/booksp_e/anrep_e/world_trade_report06_e.pdf [2020 08 27] 


\title{
THE IMPORTANCE OF ENVIRONMENTAL SUBSIDIES FOR THE ENVIRONMENT AND THE ECONOMY: THEORETICAL APPROACH
}

\author{
Kristina Gesevičiené1 ${ }^{1}$, Baiba Rivza² ${ }^{\text {, Astrida Miceikiené }} \dot{3}^{3}$ \\ ${ }^{1}$ Phd st. Vytautas Magnus University.Universiteto 10, Akademija, Kaunas distr., Lithuania. E-mail \\ kristina.geseviciene@vdu.lt \\ ${ }^{2}$ Prof. dr. Latvia University of Life Sciences and Technologies. 2 Liela Street, Jelgava, Latvia. E-mail b.rivza@llu.lv \\ ${ }^{3}$ Prof. dr. Vytautas Magnus University.Universiteto 10, Akademija, Kaunas distr., Lithuania. \\ E-mail astrida.miceikiene@vdu.lt
}

\begin{abstract}
Summary
Climate change is already having a far-reaching impact on ecosystems, economic sectors and human health and well-being. The further growth of greenhouse gases in the atmosphere is one of the main problems with climate change. Subsidies have a significant impact on the economy while having a negative impact on the environment, and their application should be improved. The aim of the study is by identifying the definition and purpose of direct environmental subsidies and tax incentives is to theoretically substantiate their significance for the environment and the economy. Most research focuses on the assessment of direct environmental subsidies, while tax subsidies as 'hidden' offbudget subsidies get less attention to. The European Union is committed to eliminate environmentally harmful subsidies in order to offset the effects on the climate and implement a socially justified and cost-effective reform of business support. The study analyzes the definition of subsidies, identifies the types of environmental subsidies, theoretically substantiates their significance for the environment and the economy.
\end{abstract}

Key words: environmental protection, subsidy definition, environmentally harmful subsidies. JEL codes: Q50, Q56, Q58. 